\title{
High prevalence of dental fluorosis among schoolchildren in three villages in Vavuniya District; an observational study
}

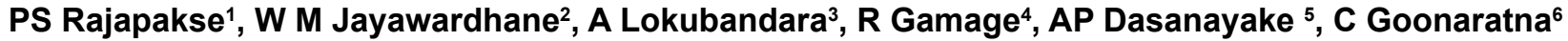

\begin{abstract}
Background Studies of groundwater sources in Sri Lanka show that in the entire Northern, North Central, Uva and Eastern Provinces, and also in a large area of the North Western Province, groundwater fluoride content is within the range $1.0 \mathrm{mg} / \mathrm{l}$ and $3.0 \mathrm{mg} / \mathrm{l}$. The $\mathrm{WHO}$ recommended safe upper limit of fluoride for drinking water is $1.5 \mathrm{mg} / \mathrm{l}$.

Objective Our objective was to determine the prevalence and degree of dental fluorosis in a cohort of schoolchildren in Sinnasippikulam in Vavuniya District, the fluoride content in their serum and urine, and fluoride levels in drinking water in dug wells of the area.

Methods Invitations in Tamil and Sinhala were sent to all households by courier. Demographic information and oral hygiene practices of 307 responsive children were recorded by interviewing children and their mothers. Detailed clinical examinations were performed according to WHO basic methods, with some modifications. Assessment of dental fluorosis in the children was done according to Dean's Index codes and criteria.
\end{abstract}

Results We found drinking water sources (dug wells) in Sinnasippikulam $(n=82)$ to have a high mean concentration of fluoride ( $\bar{x} 1.58+0.69 \mathrm{mg} / \mathrm{l})$. Of 307 children examined, $224(72.9 \%)$ had clinical evidence of dental fluorosis of varying degrees of severity. The mean fluoride level in serum of schoolchildren was $0.198 \mathrm{mg} / \mathrm{l}(\mathrm{SD}+0.074$; S.E.M. 0.013), and in their urine, $1.44 \mathrm{mg} / \mathrm{l}(\mathrm{SD}+0.59$; SEM 0.11)

Conclusions Our results show that harmful levels of fluoride are extremely common in groundwater sources in the study area, and consequently, dental fluorosis is highly endemic (72.9\%) among resident schoolchildren.

Ceylon Medical Journal 2017; 62: 218-221

DOI: http://doi.org/10.4038/cmj.v62i4.8570

\section{Introduction}

Naturally occurring fluoride in drinking water in the right concentration $(<1.5 \mathrm{mg} / \mathrm{l})$ can protect teeth from caries but higher concentrations can cause disfiguring dental fluorosis commencing in early childhood, and when imbibed over a long period by children and later by adults in large volumes - as occurs in hot tropical countries crippling skeletal fluorosis. The earliest published report we could find of dental fluorosis among Sri Lankan schoolchildren is a 1973 study from the North Central Province, which reported a prevalence of $77 \%$, and high concentrations of fluoride in randomly selected wells [1]. The first extensive report of dental fluorosis among schoolchildren in the island in 1974 found that, overall, $55 \%$ among them had dental fluorosis, with striking regional variations [2]. The community fluorosis index (CFI), based on a 2002 survey among schoolchildren in three schools in high fluoride groundwater areas $(>1.5$ $\mathrm{mg} / \mathrm{l}$ up to $10.9 \mathrm{mg} / \mathrm{l}$ ) of Anuradhapura District, found CFI values in the range $1.85-2.29$ [3]

A landmark publication on medical geology in Sri Lanka has noted that dental fluorosis frequently occurs when the fluoride content of drinking water exceeds 1.5 $\mathrm{mg} / \mathrm{l}$, and such water is habitually consumed by young children [4]. The findings of this publication have been extended by a later study, which provides a map of Sri Lanka based on fluoride levels of 14,500 samples of groundwater from both shallow and deep wells in 45 locations in seven Provinces, excluding the Central and Northern Provinces [5]. According to this study, vast swathes of the North Central, Eastern and Uva Provinces have groundwater concentrations between 1.0 and 1.5 $\mathrm{mg} / \mathrm{l}$, with many areas within them having between 1.5 and $2.0 \mathrm{mg} / \mathrm{l}$, and other locations having over $2.0 \mathrm{mg} / \mathrm{l}$. These findings indicate that dental fluorosis is likely to be highly prevalent in the island's dry zone, and that more than two million people are at risk of being victims of this condition [4]. These studies and a more recent study

1Department of Medicine and Periodontology, Faculty of Dental Sciences, University of Peradeniya; 2Consultant Civil Engineer; 3Research Assistant and 4Senior Research and Development Officer, Link Natural Products (Pvt) Ltd., Kapugoda; 5New York University College of Dentistry; 6Registrar, Ceylon Medical College Council, Colombo 8.

Correspondence: CG, e-mail: <si7np5e@gmail.com>. Received 21 August 2017 and revised version accepted 14 September 2017 
are of particular significance because they define, many localised variations in fluoride content of groundwater within Districts and also within many villages, that would explain the scattered distribution of clinically apparent dental fluorosis among people living in contiguous land areas $[4,5,7]$.

The objective of our study was to determine the prevalence and degree of dental fluorosis in a cohort of schoolchildren within the Divisional Secretary Division of Vengalcheddikulam in Vavuniya District, the fluoride content in their serum and urine, and fluoride levels in drinking water in dug wells of the area.

\section{Methods}

There were 548 households registered for our study from Mankulam, Anavilundan and Sinnasippikulam villages. An overwhelming majority of them used water from dug wells for drinking and cooking, and we have recorded the fluoride levels in 82 such wells, selected by using a series of random numbers, starting from the closest household to the main road in each village.

In order to recruit schoolchildren for the relevant part of our study, invitations in Tamil and Sinhala were sent to all households by courier informing residents that dental clinics for children would be conducted on four specified weekends by a Consultant from the Faculty of Dental Sciences of Peradeniya University, assisted by a qualified dental surgeon. In response to the invitations, 307 children out of 418 eligible children in the 548 households attended these clinics with their mothers.

Table 1. Prevalence of fluorosis among sample of school children

\section{CKDu Patients}

$(n=37)$

\begin{tabular}{ll}
\hline Gender & \\
Boys & $168(54.7)$ \\
\hline Ethnicity & $302(98.3)$ \\
Muslim & $4 \quad(1.3)$ \\
Tamil & $1 \quad(0.3)$ \\
Sinhalese & $23(20.7)$ \\
\hline Age & $184(59.9)$ \\
$<8$ years & $100(32.6)$ \\
$8-12$ & \\
$>12$ years & $36(11.7)$ \\
\hline Severity of dental fluorosis & $66(21.5)$ \\
Doubtful, present & $64(20.8)$ \\
Very mild & $37(12.0)$ \\
Mild & $21(6.8)$ \\
Moderate & $\mathbf{2 2 4}(\mathbf{7 3})$ \\
\hline Severe &
\end{tabular}

Basic demographic information and oral hygiene practices were recorded by interviewing the children and their mothers. Detailed clinical oral examinations were performed with the child in a sitting position under daylight, using mouth mirror and probe, and artificial lighting when necessary, according to WHO basic methods with some modifications, in view of the limited facilities available in the given setting [8]. Dental caries was identified using standard criteria, and recorded as total number of decayed teeth per mouth, and gingivitis was recorded as present when there were signs of inflammation, viz. redness, oedema and rolled gum margins [8].

Children in small groups and their mothers were given detailed instructions on brushing of teeth and oral hygiene, and a practical demonstration using a large specially constructed model of the mouth. To reinforce the advice each child was given a complimentary children's toothbrush and a tube of toothpaste without added fluoride. Children requiring further specialized treatment were referred by letter to General Hospital, Vavuniya. Photographs of teeth with evidence of fluorosis were taken with express permission from the mothers and children.

Assessment of dental fluorosis in the children was done according to the Dean's Index codes and criteria [6]. As recommended there, coding was based on the two most severely affected teeth. When two equally affected teeth were not found, coding was based on the less affected tooth. The examiner started as stipulated at the higher end of the index (ie. severe), and eliminated each code until the decisive code was indentified.

Our study was part of a National Research Council project (NRC PPP 14-01) which includes three villages, namely Mankulam, Anavilundan and Sinnasippikulam. Ethics committee approval was obtained for our study from the Sri Lanka Medical Association (ERC/14-032).

\section{Results}

Groundwater analysis of 82 randomly selected dug wells in Sinnasippikulam revealed a mean fluoride concentration of $1.58 \mathrm{mg} / \mathrm{l}$ (SD + 0.69;SEM 0.47), with values ranging from 0.72 to $4.12 \mathrm{mg} / \mathrm{l}$. Eleven wells had

\section{Table 2. Oral health status and dental hygiene}

\begin{tabular}{ll}
\hline & $\begin{array}{l}\text { CKDu Patients } \\
(\mathbf{n}=\mathbf{3 7})\end{array}$ \\
\hline Caries (one or more carious teeth) & $108(45.2)$ \\
Caries and dental fluorosis & $75(31.3)$ \\
$\begin{array}{l}\text { Clinically detectable gingival or } \\
\text { periodontal inflammation }\end{array}$ & $95(39.7)$ \\
Toothbrush use & $221(92.4)$ \\
Finger use & $18(7.5)$ \\
Toothpaste use & $208(87.0)$ \\
Toothpowder use & $31(13.0)$ \\
\hline
\end{tabular}


fluoride concentrations between 1.50 and $1.99 \mathrm{mg} / 1,8$ wells between 2.0 and $2.99 \mathrm{mg} / \mathrm{l}$, and 3 wells between 3.0 and $4.15 \mathrm{mg} / \mathrm{l}$. Of the 82 wells, 22 wells $(26.8 \%)$ had fluoride concentrations far in excess of the WHO safe upper limit of $1.5 \mathrm{mg} / \mathrm{l}$.

Table 1 gives basic demographic data, and the prevalence and severity of dental fluorosis in the cohort of 307 schoolchildren examined, assessed according to Dean's Index Codes and criteria. The most striking feature evident in Table 1 is that, nearly three-fourths of the children had some degree of detectable dental fluorosis. The ethnicity of the children is, of course, consonant with that of the adult population in the relevant villages.

Table 2 gives some oral health practices and indicators noted in $239(78 \%)$ of the cohort of 307 schoolchildren recruited. Although $92.4 \%$ said they used a toothbrush and $87 \%$ said they used toothpaste for brushing teeth, nearly $80 \%$ used fluoride-added toothpaste available in the market. Their oral health, as evident from Table 2, was far from satisfactory.

We were able to recruit only 33 schoolchildren to donate "spot samples" of blood and urine for assessment of fluoride content, as some children had school examinations, and others declined to have venesection or to provide urine samples. In these 33 schoolchildren the maximum level of urinary fluoride was 2.63 and the minimal level was $0.42 \mathrm{mg} / \mathrm{l}$. Twelve children had urine fluoride levels in excess of $1.5 \mathrm{mg} / \mathrm{l}$, with six of them having levels in excess of $2.0 \mathrm{mg} / 1$.

\section{Discussion}

We systematically studied the prevalence and severity of dental fluorosis in 307 schoolchildren residing in three villages within Vavuniya District. We also measured the serum and urinary levels of fluoride in 33 children, and the fluoride levels of 82 randomly selected dug wells supplying well over 200 households (of a total of 548) with water for drinking and cooking, because frequently, one dug well was used for drinking water by 2,3 or more than 3 households. So the 82 wells examined would have provided drinking water for about one-half of the 548 households.

This is the first study in Sri Lanka, to the best of our knowledge, that has combined a systematic examination of a majority of schoolchildren $(n=307)$ from three villages comprising 548 households according to Dean's Index Codes for the presence and severity of dental fluorosis, concurrently with their serum and urine for fluoride, and fluoride levels in the water in dug wells $(\mathrm{n}=82)$ supplying cooking and drinking water to a majority of households in the relevant villages [6].

The fluoride content of serum, in general, does not vary much according to time of day or night, or consumption of water, or fluoride containing drinks such as tea, because renal excretion is brisk, and fluoride homeostasis is achieved shortly [9]. So "spot samples" of blood are regarded as reasonably satisfactory for assessing fluoride levels. Although urinary "spot samples" are regarded as less accurate than values obtained from 24hour collections as measures of urinary fluoride content, we had to choose the former, because our study was done under field conditions in a simple and unsophisticated village setting, where 24 -hour collections were logistically impractical, and very likely to be inaccurate [10].

The mean serum fluoride level of the schoolchildren in our study was $0.198 \mathrm{mg} / \mathrm{l}$ (SD+0.074; SEM 0.013). In $23(69.6 \%)$ mean was $>0.18 \mathrm{mg} / 1$, and in $16(48.4 \%)$ $>0.2 \mathrm{mg} / \mathrm{l}$. The range of serum fluoride, acceptable as normal in fluorosis non-endemic areas, as given by one authority is $0.02-0.18 \mathrm{mg} / \mathrm{l}$ and by another, is $0.08-1.2$ $\mathrm{mg} / \mathrm{l}[9,12]$. Hence the values we found in our study are well above these ranges. This is in keeping with the high fluorosis endemic status of the area in which they live.

The "normal values" given by authors regarding urinary fluoride content tend to vary widely. For example, one widely quoted study states that in healthy people, living in fluorosis non-endemic areas, with drinking water fluoride content less than $0.5 \mathrm{mg} / \mathrm{l}$, the urinary fluoride fluctuates between 0.6 and $2.0 \mathrm{mg} / 1$ [11]. Another equally extensively quoted source gives normal urinary fluoride content of 24-hour collections of healthy children and adolescents as between 0.08 and $1.2 \mathrm{mg} / \mathrm{l}$ in non-endemic areas with drinking water fluoride content less than 1.0 $\mathrm{mg} / \mathrm{l}$ [12]. A recent study from Haryana, India reported that, in a cohort of 205 children from Dadanpur $94.6 \%$ had dental fluorosis and the mean urinary fluoride level was $1.71+0.13 \mathrm{mg} / 1$ [14]. In our study the mean urinary fluoride level was $1.44 \mathrm{mg} / \mathrm{l}(\mathrm{SD}+0.59$; SEM 0.11). Nearly $73 \%$ of the children had detectable dental fluorosis. Since there is a linear relationship between urinary fluoride levels and fluoride intake and intake varies widely with diet and certain beverages (especially tea), as well as with volume of water consumed, such variations are generally regarded as physiological $[12,13]$. Even so, the fact that urine fluoride levels could be measured in only 33 children may be a limitation of our study.

The results of our study show that nearly $73 \%$ of the vulnerable schoolchildren in the area had clinically detectable dental fluorosis. The high prevalence of this disorder is clearly attributable to the high fluoride content of groundwater from dug wells used for drinking and cooking, which we have established, and the resulting high levels of fluoride observed in the children's blood.

All the affected children's mothers expressed serious distress about the disfigurement of their children's teeth, during discussions we had with them, particularly in regard to their future higher education, employment and marriage. The older children, aged 11 years or more, also admitted that they felt shy to show their teeth to others, and teenage girls expressed similar worries particularly about marriage.

We contributed to the oral health of children of the study area by education, demonstration of oral hygiene technique, by distributing children's toothbrushes, and tubes of a herbal toothpaste without added fluoride, free of charge.

We conclude that dental fluorosis is a highly endemic problem in several areas of Vavuniya District, requiring further epidemiological study. Its prevention by education and provision of fluoride content reduced water is both simple and essential as eloquently elaborated by a famous scientist [11]. 


\section{Funding}

The study was funded by the National Research Council of Sri Lanka and Link Natural Products Private Ltd., a Private-Public Partnership (NRC-PPP/14-01) venture.

\section{Acknowledgements}

We thank Professor Rohana Chandrajith, Department of Geology, University of Peradeniya, Sri Lanka, for all fluoride assays in serum and urine; Professor Lal Chandrasena, Director, Nawaloka Metropolis Laboratories, Sri Lanka, for providing all other biochemical laboratory assays at special concessionary rates; Ms Chandani Rupasinha for statistical advice; and $\mathrm{Mr}$ Bandula Prematillake for laboratory tests on water samples. Ms Saroja Ratnayake and Ms Surangi Perera gave us secretarial assistance, and Mr. Manju Wijesundara rendered unfailing logistics support. This study could not have been done without the enthusiastic support of schoolchildren, schoolteachers, school principals, and people of Sinnasippikulam, and we thank them.

\section{Conflicts of interest}

PSR, WMJ,AL, RG,APD and CG declare no competing interests. RG is Senior Research and Development Officer, Link Natural Products (Pvt) Ltd.

\section{References}

1. Senevirathne B, Senevirathne K, Hettiarachchi J, Thambapillai S. Assessment of fluoride content of wells selected randomly and after examining schoolchildren for dental fluorosis. Bull World Health Org 1973; 49: 419-22.

2. Senevirathna B, Thambipillai S, Hettiarachchi J, Senevirathne K. Endemic dental fluorosis in Ceylon. Trans R Soc Trop Med Hyg 1974; 68: 105-13.

3. Abayaratna S. Community fluorosis index in children of 3 schools in the Anuradhapura District. J Sri Lanka Dent Assn 2002; 31: 70-6.

4. Dissanayake C. Of stones and health: Medical geology in Sri Lanka. Science 2005; 309:883-8.
5. Chandrajith R, Padmasiri JP, Dissanayake CB, Prematilaka KM. Spatial distribution of fluoride in groundwater of Sri Lanka. J Natn Sci Found Sri Lanka 2012; 40: 303-9.

6. Dean HT. The investigation of physiological effects by the epidemiological method In: Fluoride and Dental Health Ed: Moulton FR. American Association for the Advancement of Science 1942; Publication No.191:23-31.

7. Dissanayake CB. Water quality in the dry zone of Sri Lanka - some interesting health aspects. J Natn Sci Found Sri Lanka 2005; 33: 161-8.

8. WHO Expert Committee on Oral Health Status and Fluoride: Fluorides and oral health. Technica Report (1994). World Health Organization, Geneva, Switzerland.

9. Whitford GM. Intake and metabolism of fluoride. Adv Dent Res 1994; 8: 5-14

10. Reddy DR, Rammohan RaO MV, Murthy JM. Urinary fluoride excretion in skeletal fluorosis. Fluoride 1984; 17: 243-6

11. Susheela AK. Fluorosis: an easily preventable disease through practice of interventions. Fluorosis Research and Rural Development Foundation Delhi:2005.

12. Spak C-J, Berg U, Ekstrand J. Renal clearance of fluoride in children and adolescents. Paediatrics 1985; 75: 575-9.

13. Reddy DR. Neurology of skeletal fluorosis. Neurology India 2009; 57: 7-12.

14. Kumar S, Lata S, Yadar J, Yadar JP. Relationship between water, urine and serum fluoride and fluorosis in schoolchildren of Jhajjar District, Haryana, India. Applied Water Science 2016; 15: 21-29. 